\title{
? to ? What a way to make a livin' : The Court of Justice and the obligation to record working time
}

\author{
C-55/18, Federación de Servicios de Comisiones Obreras (CCOO) v Deutsche Bank SAE
}

\author{
Marco Rocca*
}

\section{Summary of the decision}

The Audiencia Nacional (National High Court, Spain) asks the Court of Justice of the European Union whether a legal framework that does not impose an employer obligation to record daily working time is compatible with the Working Time Directive and the EU Charter of Fundamental Rights. Although the directive does not include such an explicit obligation, the Court concludes that the absence of such a system would undermine the effectiveness of the directive. The Court's reasoning is underpinned, first, by the importance of the limitation of working time for the protection of health and safety of workers. Second, the Court stresses the weaker position of the worker in the employment relation, which makes it even more important to establish a way to prove eventual violation of working time limits and rest periods. Exceptions to the obligation should be narrowly construed and can be based only on sectoral specificities, undertaking characteristics and on situations where the working time is not measured or predetermined or can be determined by the workers.

\section{Introduction}

The case at hand, decided by the Grand Chamber of the Court of Justice of the European Union deals with the implementation of the Working Time Directive ${ }^{1}$ (WTD) by the Kingdom of Spain, and notably with the interpretation given by the Spanish Supreme Court of the national law implementing the directive. ${ }^{2}$ The Sala de lo Social of the Tribunal Supremo, had in fact decided that Spanish law mandates no obligation for employers to establish a system to record "normal" daily working time of their employees. ${ }^{3}$ This is based on a literal interpretation of the law, which only mentioned said system in connection with overtime hours. ${ }^{4}$

The claimant is the Federación de Servicios de Comisiones Obreras (CCOO), Spain's most representative trade union, joined by several other unions. The unions argue that in the absence of a system to record normal daily working time for all employees, it would be impossible not only to verify the respect of the limits set by the WTD and by Spanish legislation but also to assess whether an employee has worked overtime. Such a situation makes it impossible for worker representatives to verify compliance and obtain reliable information about working time in the undertaking. ${ }^{5}$ The unions conclude that an obligation to set up such a system can be derived from Spanish law, interpreted in light

\footnotetext{
* Researcher, CNRS (National Centre for Scientific Research) - University of Strasbourg, UMR 7354 DRES (France), https://marcorocca.wordpress.com/ .

${ }^{1}$ Directive 2003/88/EC of the European Parliament and of the Council of 4 November 2003 concerning certain aspects of the organisation of working time.

${ }^{2}$ Royal Legislative Decree 2/2015 approving the consolidated text of the Workers' Statute, 23 October 2015.

${ }^{3}$ Tribunal Supremo - Sala de lo Social, judgments no. 246/2017 of 23 March 2017 (REC 81/2016) and 338/2017 of 20 April 2017 (REC 116/2016).

${ }^{4}$ Article 35 of the Workers' Statute.

${ }^{5}$ CJEU, Case C-55/18, Federación de Servicios de Comisiones Obreras (CC.OO.) v. Deutsche Bank, 14 May 2019, ECLI:EU:C:2019:402, paras 19-20.
} 
of Article 31(2) of the EU Charter of Fundamental Rights, the WTD, and ILO Conventions no. $1^{6}$ and no. $30{ }^{7}$

The referring judge's three questions are merged into one that deals essentially with the compatibility of the Spanish legislation (as interpreted by Spanish courts) with the WTD and the Charter. Neither the Court nor Advocate General (AG) Pitruzzella have considered the trade union's ILO convention arguments.

\section{Analysis}

The Court concludes that national legislation, such Spain's, that does not require employers to set up a system for recording daily working time violates both the WTD and the Charter. ${ }^{8}$ Its reasoning can be summarized as follows.

First, the Court confirms the importance of the working time regulations for EU social law. The limitation of maximum working hours and the right to daily and weekly rest periods ${ }^{9}$ enjoy primary law relevance, per Article 31(2), and cannot be interpreted restrictively. ${ }^{10}$

Second, the Court argues that an obligation to establish a system for recording daily working time can be inferred from the requirement to ensure the effectiveness of the WTD. This is the central argument of the decision, which allows the Court to go beyond the obligations explicit in the directive. The Court emphasizes that Member States are required "to take the measures necessary to ensure" that workers are entitled to working time limitations. ${ }^{11}$ Because the worker is the weaker party in the employment relationship, ${ }^{12}$ the absence of a system to record daily working time makes it excessively difficult for workers to benefit from these limitations, ${ }^{13}$ and hinders eventual verifications from competent authorities and workers representatives. ${ }^{14}$ This approach is similar to that in the Danfoss case, which concerns equal pay for man and woman. There, the Court concluded that the lack of transparency of a system of individual pay would deprive workers of a fundamental way of enforcing the principle of equal pay. ${ }^{15}$ Here, the lack of a system for recording daily working time appears to have a similar impact on the rights recognized by the WTD.

Indeed, AG Pitruzzella had suggested that the WTD presumes the existence of "some means of recording working time". ${ }^{16}$ The Court concludes that, under the WTD, Member States are obliged to require all employers "to set up an objective, reliable and accessible system enabling the duration of time worked each day by each worker to be measured." ${ }^{17}$ This is part of the obligation of result resting upon the employer when it comes to the respect of the rights and limitations established by the WTD, clarified in case law. ${ }^{18}$ The Court also makes it clear that arguments relating to the costs of setting up a system for recording working time cannot question its conclusion. ${ }^{19}$

\footnotetext{
${ }^{6}$ Hours of Work (Industry) Convention (No. 1), 1919.

${ }^{7}$ Hours of Work (Commerce and Offices) Convention (No. 30), 1930.

${ }^{8}$ CC.OO. v Deutsche Bank, para. 71.

${ }^{9}$ WTD Articles 3, 5, and 6.

${ }^{10}$ CC.OO. v. Deutsche Bank, paras. 30-32.

${ }^{11}$ Ibid., para. 38.

12 Ibid., para. 44.

${ }^{13}$ Ibid., para. 48.

14 Ibid., paras. 56-57, 62.

${ }^{15}$ CJEU, Case C-109/88, Handels- og Kontorfunktionarernes Forbund I Danmark v Dansk Arbejdsgiverforening, acting on behalf of Danfoss, 17 October 1989, ECLI:EU:C:1989:383, para.13.

${ }^{16}$ Opinion of AG Pitruzzella, 31 January 2019, para. 77.

${ }^{17}$ CC.OO. v Deutsche Bank, para. 60.

${ }^{18}$ Court of Justice of the European Union, Case C-484/04, Commission v United Kingdom, 7 September 2006, ECLI:EU:C:2006:526, paras. 44-45.

${ }^{19}$ CC.OO. v. Deutsche Bank, para. 66.
} 
Third, the Court confirms ${ }^{20}$ that previous national case law cannot justify a violation of EU law because national courts are obliged to interpret national law in conformity with the relevant directives. ${ }^{21}$ The national precedent itself provided some clear openings to challenge it. The first of these was that, in the Spanish Supreme Court decision of March 2017, five of thirteen judges wrote dissenting opinions favoring an obligation to establish a system for recording daily working time under Spanish law. ${ }^{22}$ The second opening is in the majority decision, where the judges admit that their decision is based on the law as is, but plead for a legislative intervention to introduce the system. ${ }^{23}$

\section{Conclusions}

The immediate reaction of the media was to wonder whether the decision meant a generalized obligation of setting up a system to record daily working time, which it did. As the Court reiterated ${ }^{24}$ Member States are left to determine the specific arrangements and the technical methods of the system. In the current decision, the requirements such a system must fulfil are clear, notably: objectivity, reliability, and accessibility (for workers and their representatives). ${ }^{25}$

The Court also notes that Member States can take into account specificities related to the sector of activity, as well as the characteristics of the undertaking (such as their size), and can avail themselves of the exceptions allowed by the WTD. ${ }^{26}$ These exceptions should be interpreted narrowly, however, given that, as the Court also observes, the WTD "may not be interpreted restrictively at the expense of the rights that workers derive from it." ${ }^{27}$

The Court reached this conclusion despite the lack of any textual underpinning in the directive. Further, the ILO conventions the Spanish trade unions (nos. 1 and 30) invoked mentioned only the obligation to keep a record in the context of extra hours. ${ }^{28}$ After all, faced with an essentially identical framework, derived from EU and Spanish legislation, the Spanish Supreme Court had come to the opposite conclusion.

Changes in the Spanish legal order before the decision confirm the appropriateness of the Court's reasoning. Indeed, the center-left government introduced the obligation to record daily working time for all employers in the working day registry with the Decree 8/2019 of 8 March 2019. ${ }^{29}$ Early reports of the impact of this measure appear to confirm the effectiveness approach the Court deployed. In particular, the Spanish National Institute of Statistics found a reduction of 11 percent over 2018 in the number of overtime hours during the three months following the entry into force of the new system. ${ }^{30}$

The current decision is the second time that the Federación de Servicios Privados of the trade union Comisiones obreras was able to successfully bring legal proceedings before the Court under the WTD. ${ }^{31}$

\footnotetext{
${ }^{20}$ See also the precedent of CJEU, Case C-441/14, Dansk Industri (DI) v Estate of Karsten Eigil Rasmussen, 19 April 2016, ECLI:EU:C:2016:278.

${ }^{21}$ CC.OO. v. Deutsche Bank, para. 70.

${ }^{22}$ Tribunal Supremo, judgment 246/2017, 19-43.

${ }^{23}$ Ibid., 14-15.

${ }^{24}$ CC.OO. v. Deutsche Bank, para. 63.

${ }^{25}$ Ibid., para. 60 (inter alia).

${ }^{26}$ Ibid., para. 63.

${ }^{27}$ Ibid., para. 32.

${ }^{28}$ Respectively Articles 8 and 11.

${ }^{29}$ Real Decreto-ley 8/2019, de medidas urgentes de protección social y de lucha contra la precariedad laboral en la jornada de trabajo.

30 El País, "Las horas extra pagadas caen un $19 \%$ tras la entrada en vigor del registro obligatorio de jornada," 28 August 2019, accessed 4 September 2019, https://elpais.com/economia/2019/08/27/actualidad/ 1566927700 300044.html.

31 The first time being Case C-266/14, Federación de Servicios Privados del sindicato Comisiones obreras $v$. Tyco Integrated Security SL and Tyco Integrated Fire \& Security Corporation Servicios SA, 10 September 2015,
} 
Another case, which helped pave the way for the politically sensitive revision of the Posting of Workers Directive, was also brought forward by a Finnish trade union. ${ }^{32}$ This strand of cases highlights the enduring ability of national actors to influence EU law and policy through well-targeted litigation, as well as of national trade unions to defend and expand the worker rights across Europe.

Our last point concerns what the Court did not say. Notably, the defendant (Deutsche Bank) had invoked the freedom to conduct a business, enshrined in Article 16 of the Charter, to dispute the obligation to introduce a system to record daily working time. AG Pitruzzella denied the relevance of this freedom. ${ }^{33}$ The Court in its turn did not engage, missing an opportunity to clarify the balance between the protection of social rights and the freedom to conduct a business, whose invocation is becoming a staple in disputes surrounding employment rights, after the "successes" in previous cases. ${ }^{34}$ The clarification would have been all the more appropriate considering that the Spanish Supreme Court had referred to the principle of the freedom to conduct a business (el principio de libertad de empresa) to deny the existence of the obligation to record daily working time..$^{35}$

ECLI:EU:C:2015:578. See Sarah De Groof, "Travelling time is working time according to the CJEU... at least for mobile workers," European Labour Law Journal 6, no. 4 (2015): 386-91.

32 CJEU, Case C-396/13, Sähköalojen ammattiliitto v Elektrobudowa Spolka Akcyjna, 12 February 2015, ECLI:EU:C:2015:86.

${ }^{33}$ Opinion of AG Pitruzzella, para. 82.

${ }^{34}$ See Cases C-157/15, G4S Secure Solutions v G4S Secure Solutions NV, 14 March 2017, ECLI:EU:C:2016:382; C-188/15, Bougnaoui and ADDH v Micropole SA, 14 March 2017, ECLI:EU:C:2017:204; C-426/11, Alemo Herron v Parkwood Leisure Ltd, 18 July 2013, ECLI:EU:C:2013:521.

${ }^{35}$ Tribunal Supremo, judgment no. 246/2017, 16. 